Journal of Community Based Environmental Engineering and Management, 2021, Vol. 5, No. 2: 133-140

\title{
DEVELOPMENT OF FISH FARMING IN BUCKETS SYSTEM AND INNOVATION OF PROCESSED PRODUCTS TO IMPROVE COMMUNITY RESILIENCE IN THE FACE OF THE COVID-19 PANDEMIC
}

\author{
Andri Akbar ${ }^{1 *}$, I Gusti Putu Octavio ${ }^{1}$, Rida Aini Rahmawati ${ }^{2}$ \\ ${ }^{1)}$ Integrated Terminal Jakarta, PT. Pertamina (Persero), Indonesia \\ ${ }^{2)}$ Faculty of Fisheries and Marine Science, Institut Pertanian Bogor, Indonesia
}

\begin{abstract}
The Covid-19 pandemic has an impact in all fields, namely in terms of health, social, economic, and food. Reduced income or even job loss to cause a decrease in the ability to meet basic needs, namely family food needs. Corporate Social Responsibility (CSR) of Pertamina Corporation Integrated Terminal Jakarta initiated collaboration between community groups and various stakeholders through the integration of the budikdamber system and the development of processed product innovations done in Rawa Badak Selatan Village, Koja District, North Jakarta as the Area 1 Company's Ring. The development of processed innovation products is carried out together with the Bunda Koja group by carrying out all contain catfish product (ACE) activities. ACE's budikdamber activities are empowered by cultivating fish and vegetables in buckets carried out in several yards of residents of the Rawa Badak Selatan Village. This activity is expected to contribute to the community's resilience in the face of pandemics by increasing knowledge and skills in developing mental systems and their processed products. The implementation of activities is carried out by training methods and the application of mentoring. The community generally feels helped because the process of making processed and ACE budikdamber is empowered to facilitate for the community to get nutritious food. This activity also has an impact on improving nutrition and socioeconomics of toddler parents, through training in nutritious catfish processed products, toddler mothers can learn to understand the importance of nutritious food for toddlers.
\end{abstract}

Keywords: Budikdamber, Nutritious food, Pandemic

\section{Introduction}

Coronavirus disease 2019 (Covid-19) by SARSCoV-2 virus (Severe Acute Respiratory Syndrome Coronavirus-2) is a new disease that have to watch out for due to relatively rapid transmission, having a mortality rate that cannot be ignored. The World Health Organization

${ }^{*}$ Corresponding Author:

E-mail: andriebar@gmail.com

Received: 2 September 2021

Revised: 18 September 2021

Accepted: 19 September 2021

DOI: $10.23969 /$ jcbeem.v5i2.4539
(WHO) on January 30, 2020 has designated the Covid-19 pandemic as a public health emergency of international concern (Susilo et al., 2020). Data from the Ministry of Health said that on August 12, 2021, the accumulation of the total number of positive Covid-19 in Indonesia reached 3,774,155 people, with patients dying by 113,664 people (Ministry og Health, 2021).

The Covid-19 pandemic has an impact in all fields, not only in terms of health, the impact of the pandemic also affects the social, economic, and food sectors. The Food and Agricultural Organization (FAO) states that the Covid-19 pandemic affects food supply and demand, and 
indirectly through decreased purchasing power, capacity to produce, and distribute foodstuffs (Hirawan and Verselita, 2020). The Covid-19 pandemic also led to reduced income or even job losses. Reduced family income leads to a decrease in the ability to meet basic needs, namely family food needs (Suryana et al., 2020). Rawa Badak Selatan Village (KRBS) is one of the villages in Koja District, North Jakarta with the most populous population compared to other villages. Rawa Badak Selatan Village has an area of $1,0162 \mathrm{~km}^{2}$ or $7.70 \%$ of the area of Koja District. The population of Rawa Badak Selatan Village in 2018 amounted to 51,889 people, while the overall population in Koja District was 334,876 people out of a total of 6 villages (BPS, 2020). Increasing the number of people can cause various problems including limited employment so that it will have an impact on the family economy, health problems and the number of unemployed that can cause rising poverty (Saribanon et al., 2020).

The technique of fish cultivation in buckets (Budikdamber) was first proposed by Juli Nursandi, lecturer from the Faculty of Aquaculture from Lampung State Polytechnic. This technique can be done by utilizing limited land (Nursandi, 2018). This method combines a hydroganic system with a fish farming pond underneath. Hydroganic system is a hydroponic farming system but is done organically pond water containing fish manure will be an additional source of nutrients for plants. Hydroponics technology provides an alternative in narrow areas to be able to produce food sources with environmentally friendly systems. The advantage of this system is that it can cultivate vegetables and fish, so that the fulfillment of family nutrition during the Covid19 pandemic can be fulfilled properly (Suryanti et al., 2020).

Government policies are made to avoid Covid19 transmission are carried out by reducing or limiting outdoor activities or Large-Scale Social Restrictions (PSBB). This policy affects the fulfillment of basic needs for the family. The government also imposed Work from Home (WFH) reminding the wider community to stay at home only and not leave the house if there are no activities or very urgent affairs (Besila et al., 2021). Corporate Social Responsibility (CSR) of Integrated Terminal Pertamina Corporation in Jakarta initiated collaboration between community groups and various stakeholders by integrating the budikdamber system and developing processed product innovations conducted in Rawa Badak Selatan Village, Koja District, North Jakarta as the Area 1 Company's Ring.

Budikdamber activities are carried out by cultivating catfish along with kale vegetables. The advantages of catfish are that they have high adaptability to environmental conditions and very fast growth (Zulisyanto, 2016). The development of processed innovation products and the Bunda Koja Group are carried out by carrying out all-catfish elements (ACE) activities. This activity is expected to contribute to the community's resilience in dealing with the Covid-19 pandemic by increasing knowledge and skills in developing the budikdamber system and its processed results in a sustainable manner to positively impact economic, social, and environmental aspects.

\section{Research Methodology}

Research Location

The implementation of the activities was done in Rawa Badak Selatan Village, Koja District, North Jakarta City. The event was held in May 2020-July 2021. The implementation of activities is done by training methods and the application of mentoring. Budikdamber activities were done in several houses of KRBS residents, training activities to make catfish processed innovation products were conducted at Hamlet number 01's Hall. 


\section{Implementation Method}

ACE's empowered activities are fish and vegetable cultivation activities in buckets (budikdamber) done in several yards on Rawa Badak Selatan Village. The CSR team provides the facilities and infrastructure of this activity. Preparation is done by preparing 10 units of budikdamber media as the initial stage of this activity, and continues to grow more gradually until it reaches 75 units. Monitoring and recording is done every week. Catfish harvest is done every three months, kale can be harvested every 20-30 days. Then the harvest can be directly processed by the surrounding residents, in addition, the Bunda Koja Group also develops the harvest into a variety of innovation products all-catfish elements (ACE).

\section{All-catfish Product Innovation Development Implementation Methods}

The development of processed innovation products is carried out together with Bunda Koja Group (BKG) by carrying all-round catfish (ACE) activities. This activity also involves mothers of toddlers by making various innovations in catfish processed products and the utilization of side products in the form of catfish bones, so that the processing process is carried out with zero waste. The program series includes catfish processed innovation training, catfish processed production management assistance, and product marketing assistance.

Catfish processed innovation training consists of exposure of materials about the nutritional content of catfish, handling of catfish raw materials, and the stages of catfish process. The raw materials of making products are prepared by several members of BKG and assisted by the CSR team. Catfish processed innovation products that have been made together with all participants, namely the group of mothers of toddlers, some toddlers and the health center of Koja District can then be directly consumed and carried by all participants. ACE production management assistance is carried out by CSR team with BKG. Mentoring activities are carried out by making Production Operational Standards so that product quality is always uniform, packaging process into distribution process. The team also help provide production house facilities and standardized tools.

Product marketing assistance is done gradually. Product sales are limited to the community around KRBS. After various products have been produced and obtained a Domestic Industrial Food permit from the Ministry of Health and Master Number, the distribution process is carried out on a larger scale. BKG together with CSR team will market products through social media and various marketplaces.

Data Collection and Analysis Methods

Data collection is done with observations and interviews. Qualitative data analysis with descriptive elaboration describes the stages of implementation. Sources of Information about the implementation of activities in this research include CSR Integrated Terminal Pertamina Corporation in Jakarta as an informant implementing the program, mother koja group, toddler mothers, and the community around Rawa Badak Selatan Village as the recipient of the program. 


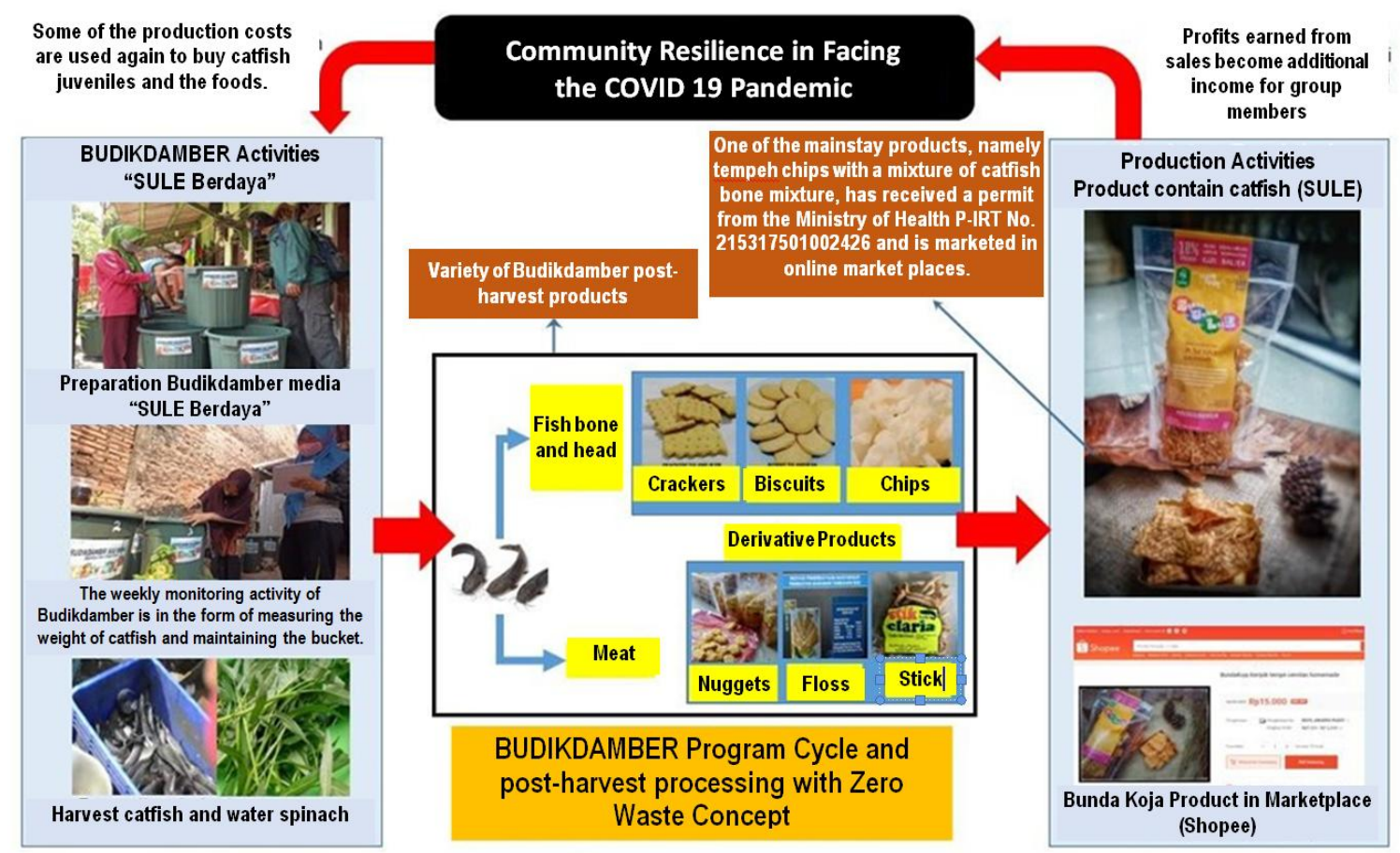

Figure 1. Integration of Budikdamber powered activities and ACE production

\section{Result and Discussion}

\section{Budikdamer and All-Catfish Activities}

The preparation of ACE activities is empowered by socializing and educating about the process of budikdamber biosystem, the advantages of budikdamber system that can be placed in narrow or limited areas, more efficient water use, additional planting of kale vegetables to meet vegetable needs, easy for people to do in the yard and able to meet nutritious food needs.

The next stage is to determine the place to be used to place the budikdamber media. The land area needed for one medium is $0.2 \mathrm{~m}^{2}$, this medium is able to accommodate 50 catfish with a density of 1 head/L. The number of media as many as 10 units is expected to reach $50 \mathrm{~kg}$ assuming 1 bucket produces $5 \mathrm{~kg}$ of catfish in one period for 3 months. The top of the budikdamber can also be placed 10 pots of kale plant media, with a harvest period of 20-30 days. The initial stage after planning the preparation of the place and the media is to carry out the cultivation process and maintenance in accordance with the techniques carried out by Nursandi (2020). Budikdamber bucket unit that has been prepared, filled with water until it reaches a volume of 80 Liters, the top of the bucket is hung with plastic cups containing wood charcoal as a medium of planting kale. In order for kale plants to grow well, plastic cups are given small holes as a place of entry of water into the growing medium of kale. Catfish seeds used measuring $11-13 \mathrm{~cm}$ as much as 50 tails in one unit budikdamber. Catfish feed used is feed in the form of pellets whose size is adjusted to the size of catfish.

Budikdamber maintenance by the residents is done regularly with periodic water draining, feeding and weekly monitoring. Feeding is done three times a day, the amount of feed given will be adjusted to the size and weight of the catfish. Weekly monitoring is done to determine the growth of catfish by sampling measurements of weight, length, and width of catfish. Draining is also done periodically every two to three weeks. 


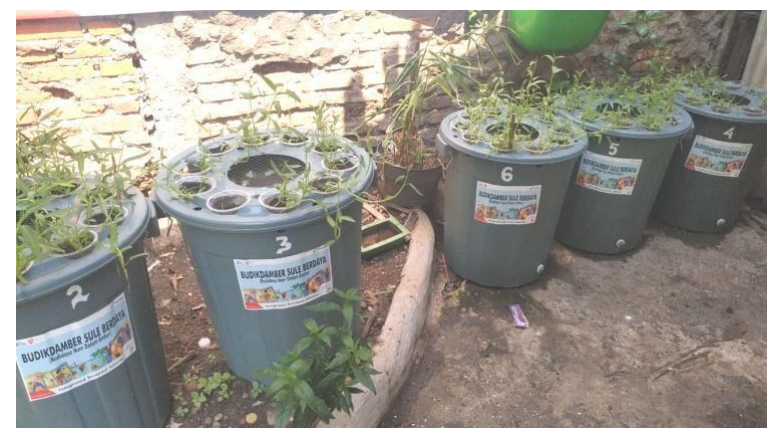

Figure 2. ACE Budikdamber empowered in the yard of Rawa Badak Selatan resident

The process of harvesting kale is done every 2030 days, by cutting the base, so there is no need to sow seeds, kale plants can grow from the base and can be harvested again. The process of harvesting catfish can be done after three months. The harvest of kale can be done up to three times for three months. The Bunda Koja group partly utilizes the harvest from this ACE empowered activity as raw material for all-round catfish innovation products. Crops are also marketed around the Koja District area. Estimated income in doing budikdamber as many as 10 buckets based on Saribanon (2020) is estimated to reach $\pm \mathrm{Rp}$. 3,000,000.00- for 3 months budikdamber's period.

The existence of this program becomes a hope for the community in the Rawa Badak Selatan Village. The community responds to this program positively because the community generally feels helped by the existence of this program. The process of making and maintaining it is not too difficult and is still relatively easy for the community to follow the maintenance process until the harvest process.

\section{ACE Product Development Activities}

This activity was held at Hamlet number 01's Hall, Rawa Badak Selatan Village, Koja District, North Jakarta City. The implementation of activities is done by training methods and the application of mentoring. The BKG of 10 people and mothers who have toddlers amounted to 5 people as subjects in each activity, accompanied by CSR Pertamina team, IPB academics, and Koja District health center. The training and mentoring system is carried out with direct practice, so that the $\mathrm{BKG}$ can actively understand the material provided.

Training activities involving IPB academics in the field of processing of aquatic products, processes and techniques for making various products are carried out in accordance with the guidelines of materials that have been prepared in advance. The material presented in each session is education about the nutritional content of catfish, its economic value, the importance of nutritional intake for toddlers, and various processed catfish products. The output of this activity is that mothers who have toddlers and BKG understand the importance of nutritional intake and how to make processed from nutritious catfish.

Catfish processed innovation training is divided into three meeting sessions. The first session was the making of nuggets and catfish flakes. The second session is the manufacture of catfish sticks, and the third session is the utilization of catfish bone side products into cracker products, fish bone tempeh chips, and biscuits. IPB academics guide each session training, the material is displayed with an LCD, so that all participants can listen well. The activity continued with the direct practice of making processed catfish with all participants. Products are made with larger protein components. Catfish nuggets are made with a composition of catfish meat as much as $60 \%$, while the composition of meat in abon products as much as $64 \%$.

Utilization of fish bones in the previous production process becomes an untapped byproduct even though there is a high calcium and phosphorus content. The bones and head of catfish have a calcium content $9.35 \%$ higher than catfish meat which is only $0.65 \%$. In addition to calcium, catfish bones contain 
phosphorus, magnesium, potassium, and sodium (Handayani and Kartikawati, 2015).

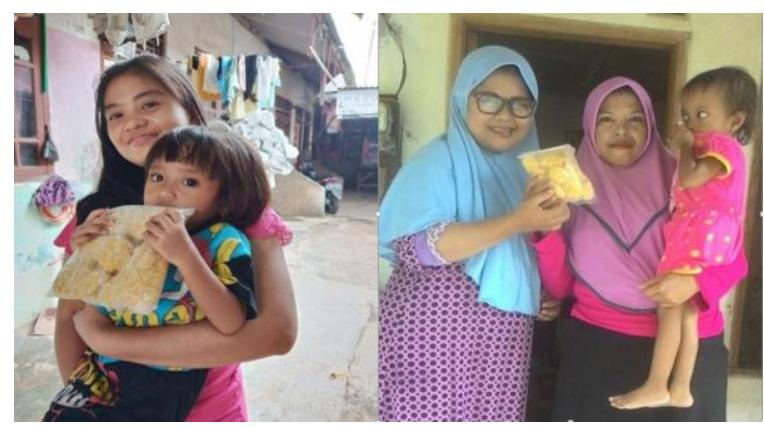

Figure 3. Nugget products given to toddlers in the area around Rawa Badak Selatan Village

The results of catfish processed innovation products that have been made can be directly tried by all participants. During the training activities, the enthusiasm of participants was quite good, through discussion sessions many questions were submitted related to the material, curiosity about catfish and processed fish and business opportunities. The group of koja mothers and toddler mothers can gain new knowledge about making nuggets and flakes. The results obtained from this activity include a variety of products made with a nutrient-dense composition and can be liked by many circles. Children and toddlers more taste nugget products. Abon products and tempeh chips are more tasted by mothers.

\section{ACE Production Management}

The BKG carries out the process of processed catfish by involving mothers of toddlers, starting with the preparation of Production Operational Standards and the preparation of good sanitary and hygiene standards. The process of catfish is very attentive to cold chain production so that every nugget product after completion of production then distribution is always frozen. Sanitation and hygiene are done by always washing hands with soap before and after production activities and using masks and gloves to prevent contamination. Equipment and production sites are always in a clean state after and before production.

Flakes products, nuggets, and fish bone tempeh chips have gone through the production stage. The process of producing nuggets begins by mixing catfish meat with egg yolks, fine garlic, salt, and sugar using a blender then the mixture is added carrots, tapioca and stirred until even. The nugget dough is then steamed for 30 minutes. The batter that has been cooked is cut to the desired size, smeared with tapioca flour and then smeared with egg whites then bread flour. And then, it can be directly fried or stored in the freezer. The process of making catfish flakes begins by sautéing a fine seasoning, then lemongrass, galangal, bay leaves, orange leaves, brown sugar and coconut milk. Catfish meat that has been steamed and sifted then put into the seasoning mixture then continue to be cooked until dry browned, after ripe and not hot, then directly packaged in plastic.

The implementation of production activities is also accompanied by financial management assistance so that the BKG and mothers of toddlers are able to plan the business of processed meat and catfish bones in a sustainable manner. Assistance in the process of calculating the cost of production in catfish processed products includes the calculation of consumable costs, necessary equipment costs, depreciation costs of tools adjusted to production capacity. The Pertamina CSR team provides assistance for packaging and equipment needed during the production process.

The process of producing flakes, nuggets, and fish bone tempeh chips is done once a week. Some products will be given to several toddlers around the Village as additional food every month. Assistance is also carried out until the issuance of the Attempted Master Number permit. Fish bone tempeh chips have also been obtained household industrial food from the Ministry of Health. 


\section{ACE Products Marketing}

Product marketing assistance is done gradually, initial sales are limited to the community around the Village. Products of processed catfish creations BKG introduced off-line with the distribution of products to various stalls, outlets or stores. They also conducted hearings with various agencies such as the exit party, the Food and Drug Supervisory Agency (BPOM), and the Mayor of North Jakarta to be able to introduce a variety of ACE products and positive impacts for toddler parents and the surrounding environment.

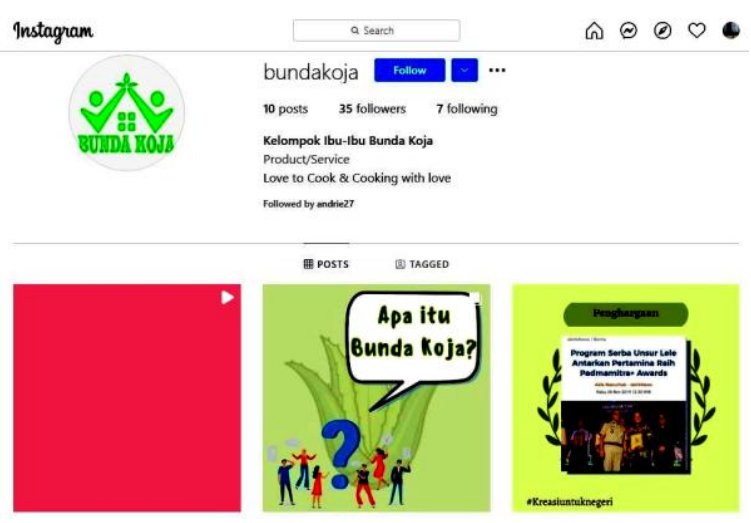

Figure 4. Bunda Koja Group on Social Media

Bunda Koja group, together with Pertamina CSR team has also been marketing products online through Instagram social media and the largest marketplace, Shopee. Instagram was chosen as one of the social media platforms that have supporting features for effective and efficient business continuity. Support features and the number of instagram users who jumped $40 \%$ during the Covid-19 pandemic, the development of accounts on instagram social media has a great opportunity to achieve the goals to be determined (Gunarso et al., 2021) Products that began to be produced by the BKG provide profit results of around Rp 500,000 every month. After the production house facilities assisted by Pertamina CSR team has been completed, the production process can be more, the profit of production is also five times greater to reach $\mathrm{Rp}$ 2,500,000 every month.

This activity has an impact on improving nutrition and socioeconomics of toddler parents, through training in nutritious catfish processed products, toddler mothers can learn to understand the importance of nutritious food for toddlers and processed innovations from catfish that have business opportunities. Processed fish products that were successfully made by toddler mothers are a small part of it brought to be distributed to toddlers as rice companion food, so it indirectly has an impact on improving toddler parenting. In addition, as much as $10 \%$ gained from profits on each production will also be given for the improvement of toddler nutrition.

\section{Conclusion}

This activity contributes to the resilience of the community in the face of pandemics by increasing knowledge and skills in developing the mental system and its processed products in a sustainable manner. Rawa Badak Selatan people generally feel helped by the existence of ACE's empowered program and innovation products. The process of making all-catfish products and maintenance of ACE budikdamber is empowered with assistance to make it easier for the community to get nutritious food. The community can directly harvest the results of budikdamber, so that it can meet the needs of vegetables and also protein from catfish. This activity has an impact on improving nutrition and socioeconomics of toddler parents, through training in nutritious catfish processed products, toddler mothers can learn to understand the importance of nutritious food for toddlers and processed innovations from catfish that have business opportunities.

\section{References}

Badan Pusat Statistik. (2019). Kecamatan Koja dalam Angka 2019. Diakses 
pada tanggal 12 Agustus 2021. https://jakutkota.bps.go.id/

Besila, QA., Mangunsong N.I. , Debora T.P. (2021). Penyuluhan pemanfaatan lahan terbatas untuk menunjang ketahanan pangan keluarga selama masa pandemi covid 19. Akal: Jurnal Abdimas dan Kearifan Lokal 02 (01), 11-21.

Gunarso B. et al. (2020). Digital Marketing Calender untuk Bisnis Kuliner: Pendampingan Social Media Instagram@Inidapurmakwaw untuk Keberlangsungan di Era New Normal. Akal: Jurnal Abdimas dan Kearifan Lokal 02 (01), 38-61.

Handayani, D.I.W, dan D. Kartikawati. (2015). Stik lele alternatif diversifikasi olahan lele (Clarias sp.) tanpa limbah berkalsium tinggi. Jurnal Ilmiah 4(1), 109-117.

Hirawan F.B, dan A.A. Verselita. (2020). Kebijakan pangan di masa pandemi Covid19. CSIS Commentaries DMRU-048-ID. Jakarta: Centre for Strategic and International Studies.

Nursandi J. (2018). Budidaya ikan dalam ember "budikdamber" dengan aquaponik di lahan sempit. Prosiding Seminar Nasional Pengembangan Teknologi Pertanian. 129-136

PHEOC. (2021). Pos Kedaruratan Kesehatan Kementerian Kesehatan RI. Diakses Pada 13 Agustus 2021. https://covid19.kemkes.go.id/dashboa rd/covid-19

Saribanon N., Zuhriansyah, F. Ilmi. (2020). Program pengembangan olahan ikan lele dan budikdamber untuk peningkatan nilai tambah dan pemberdayaan masyarakat. Jakarta: lembaga penelitian dan pengabdian kepada masyarakat universitas nasional.

Suryana A, Rusastra I.W. , Sudaryanto T., Pasaribu S.M. (2020). Dampak pandemi COVID- 19: Perspektif Adaptasi dan Resiliensi Sosial Ekonomi Pertanian. Jakarta: IAARD Press

Suryanti S, Umami A. , Firmansyah R. , Widyasaputra R. (2020). Pemberdayaan pertanian organik dengan model hidroganik budikdamber di era pandemi covid 19 di kabupatenbantul provinsi DIY. Jurnal Agro Dedikasi Masyarakat (JADM) 1(2), 44-50.

Susilo, A. et al. (2020). Coronavirus Disease 2019: Review of Current Literatures. Jurnal Penyakit Dalam Indonesia 7(1),45-67.

Zulisyanto D, Riyadi PH, Amalia U. (2016). Pengaruh lama pengukusan adonan terhadap kualitas fisik dan kimia kerupuk ikan lele dumbo (Clarias gariepinus). Jurnal Pengetahuan dan Bioteknologi Hasil Perikanan. 5(4), 26-33. 